J. Perinat. Med. 3 (1975) 34

\section{Renal response to acid loading in the developing lamb fetus, intact in utero}

\author{
Salha S. Daniel, Edward T. Bowe, Roger Lallemand, Ming N. Yeh, \\ L. Stanley James \\ Division of Perinatal Medicine of the Departments of Anesthesiology, \\ Obstetrics and Gynecology and Pediatrics, College of Physicians and Surgeons, \\ Columbia University, \\ Babies Hospital, The Children's Medical and Surgical Center of New York
}

Received February 24, 1974. Accepted June 8, 1974.
Although it has been known that the fetal kidney is capable of producing an appreciable amount of acid and hypotonic urine $[1,9,19,20$, 21], little attention has been given to its role in the maintenance of fetal homeostasis during intrauterine development. This has been due mainly to the fact that the placenta is the principal organ regulating the composition of body fluids in fetal life. Placental permeability for certain ions, such as chloride and bicarbonate is low $[5,6,16,22]$ and the gradual accumulation of acid by the human fetus durring labor reflects the slow placental elimination of hydrogen ion $[4,7]$. Earlier experiments in our laboratory have demonstrated that when lactic acid is infused into the fetal lamb in utero, elimination of the hydrogen and lactate load by the feto placental unit takes several hours to reach completion [11]. No effort was made to identify the relative contributions by the placenta and fetal kidney. From similar experiments in newborn lambs, it seemed likely that the fetal kidney could participate in fetal acid-base homeostasis. The present studies were specifically designed to test this hypothesis.

\section{Material and methods}

Five pregnant ewes, of gestational ages ranging from 110 -118 days (term 147-150 days) were studied; food was withheld for 48 hours prior to surgery. Hysterotomy was carried out with the ewe supine, following a single injection of spinal anesthesia using $10 \mathrm{mg}$ tetracaine hydrochloride (Pontocain $®$ ). This anesthesia was supple-

\section{Curriculum vitae}

Salfia S. Daniel, $P b . D$., is a Research Associate in the Department of Anestbesiology at Columbia University, College of Pbysicians and Surgeons, New York City. Born in Iraq, she attended Battersea College of Tecbnology in London, where she received ber $B S$ degree in Chemistry. After obtaining ber $P b$. $D$. from London University, Dr. Daniel joined the Perinatal $R e-$ search Group at Columbia Medical Center; her special research interest is acid-base bomeostasis in the fetus and newborn.

mented with $2.5 \%$ sodium pentobarbital (Diabutal囚) solution given intravenously when necessary. Details of surgery have been described by GrESHAM et al. [14]. In addition to implanting catheters in fetal artery and vein, catheters were implanted in the amniotic cavity and fetal bladder via the urachus as well as maternal femoral artery. The fetus was returned to the uterus and maternal uterine and abdominal incisions closed. The intravascular catheters were filled with aqueous heparin $(1000 \mathrm{U} / \mathrm{ml})$ and refilled daily as long as the preparation was in use. When urine was not being collected, the urachal catheter was connected to the amniotic fluid catheter. Penicillin, 5,000,000 Units, and 1 gram streptomycin were given intramuscularly to the mother prior to an for two days following surgery, and subsequently after every experiment. Three. to four days recovery period were allowed and the experiments on the fetus were therefore conducted at 115 days gestation or over (range 115-125). Fetal weight ranged from 1.2 to $2.2 \mathrm{~kg}$ with an average of $1.8 \mathrm{~kg}$. All ewes had a single 
fetus; one fetus was infused twice with seven days interval between the two studies.

Each experiment consisted of $1-2$ hours of control observation following which acute acidosis in the fetus was induced by intravenous infusion of isotonic lactic acid; fifteen mMoles in $60 \mathrm{ml}(0.25 \mathrm{M}$ solution) was given per kilogram estimated fetal weight. The initial rate was $0.25 \mathrm{mMoles} / \mathrm{kg} / \mathrm{min}$ for 30 minutes followed by $0.13 \mathrm{mMoles} / \mathrm{kg} / \mathrm{min}$ for the next 60 minutes. Previous experiments had shown that this initial rapid rate is necessary to produce a prompt acidosis [11]. Arterial blood samples were taken periodically during and for 3 hours following the completion of infusion. Urine was collected anaerobically throughout the experiment in 30 or 60 minute fractions and the volume recorded. Blood and urine $\mathrm{pH}$, $\mathrm{PCO}_{2}$ and blood $\mathrm{PO}_{2}$ were determined within ten minutes after sampling using microelectrodes; and base deficit or bicarbonate was calculated with the SIGGAARD-ANDERSON nomogram [26]. Measurements on urine samples were made after rinsing the electrodes anaerobically with the fluid to ensure stable readings. Urine and blood lactate were determined by a micromodification of the method of Barker and Summerson [3]. Plasma and urine were analyzed for total solute concentration (osmolality) [8], chloride [10], sodium and potassium [23] and phosphate [2]. In addition, urine was analyzed for ammonia [25] and titratable acid [17].

\section{Results}

The effect of lactic acid infusion on blood acidbase and plasma electrolyte concentrations in six experiments are presented in Tabs. I and II and Figs. 1 and 2. Details of urine composition before and following the acid infusion are shown in Tab. III and in Figs. 1 and 2.

During the 90 minutes of infusion, blood $\mathrm{pH}$ fell from 7.36 to 7.13 , base deficit (B. D.) rose from 3.8 to $16.4 \mathrm{mEq} / \mathrm{L}$ and lactate rose from 2.2 to $14.8 \mathrm{mM} / \mathrm{L}$; there was a transient but significant

Tab. I. Mean acid-base indices ( \pm S. E.) in arterial blood in 6 experiments prior to, during and following lactic acid infusion.

\begin{tabular}{lccrrrr}
\hline $\begin{array}{l}\text { Time in } \\
\text { minutes }\end{array}$ & 0 & 30 & 90 & 150 & 210 & 270 \\
\hline $\mathrm{pH}$ & $7.364 \pm 0.0139$ & $7.114 * * \pm 0.0568$ & $7.126 * * \pm 0.0398$ & $7.230 * * \pm 0.0206$ & $7.274 * * \pm 0.0137$ & $7.292^{* *} \pm 0.0180$ \\
base deficit & & & & & & \\
$\mathrm{mEq} / \mathrm{L}$ & $3.76 \pm 1.11$ & $15.10 * * \pm 3.33$ & $16.44 * * \pm 1.99$ & $12.84 * * \pm 2.00$ & $8.78 * * \pm 1.53$ & $7.40 * * \pm 1.69$ \\
$\mathrm{PCO}_{2} \mathrm{mmHg}$ & $38.8 \pm 2.30$ & $44.7 * * \pm 1.10$ & $41.0 \pm 1.23$ & $40.7 \pm 1.23$ & $38.8 \pm 0.95$ & $39.0 \pm 0.93$ \\
$\mathrm{PO}_{2} \mathrm{mmHg}$ & $16.3 \pm 1.17$ & $19.3 * * \pm 1.00$ & $18.3 * \pm 0.92$ & $18.2 * \pm 0.53$ & $17.7 * \pm 0.75$ & $17.3 * \pm 0.80$ \\
\hline
\end{tabular}

* Significantly different from control at the $95 \%$ confidence level.

** Significantly different from control at the $99 \%$ confidence level.

Tab. II. Arterial blood or plasma composition (mean \pm S. E.) in 6 experiments prior, during and following lactic acid infusion.

\begin{tabular}{|c|c|c|c|c|c|c|}
\hline $\begin{array}{l}\text { Time in } \\
\text { minutes }\end{array}$ & 0 & 30 & 90 & 150 & 210 & 270 \\
\hline lactate $\mathrm{mM} / \mathrm{L}$ & $2.2 \pm 0.31$ & $10.6 * * \pm 1.51$ & $14.8 * \pm 2.40$ & $11.0 * * \pm 0.75$ & $9.9 * * \pm 0.53$ & $8.7 * * \pm 0.99$ \\
\hline $\begin{array}{l}\text { osmolality } \\
\text { mOsm/kg } \\
\text { sodium }\end{array}$ & $296.8 \pm 4.84$ & $299.4 \pm 8.46$ & $298.6 \pm 7.66$ & $299.8 \pm 7.35$ & $302 \pm 8.99$ & $308.6 \pm 7.88$ \\
\hline $\begin{array}{c}\mathrm{mEq} / \mathrm{L} \\
\text { potassium }\end{array}$ & $146.2 \pm 2.07$ & $139.9 * \pm 2.78$ & $137.5 * * \pm 2.11$ & $135.7 * * \pm 3.96$ & $14 Q .6 \pm 3.23$ & $147.3 \pm 2.91$ \\
\hline $\mathrm{mEq} / \mathrm{L}$ & $4.32 \pm 0.161$ & $3.86 * * \pm 0.136$ & $3.58 * * \pm 0.075$ & $3.48 * * \pm 0.106$ & $3.66 \pm 0.165$ & $4.12 \pm 0.236$ \\
\hline $\begin{array}{l}\text { chloride } \\
\mathrm{mEq} / \mathrm{L}\end{array}$ & $112.7 \pm 1.85$ & $109.6 \pm 2.23$ & $105.0 * \pm 4.50$ & $105.8 * \pm 4.63$ & $105.5^{*} \pm 4.21$ & $106.8 * * \pm 1.25$ \\
\hline $\begin{array}{l}\text { inorganic } \\
\text { phosphate } \\
\mathrm{mM} / \mathrm{L}\end{array}$ & $2.09 \pm 0.178$ & $2.22 \pm 0.115$ & $2.30 \pm 0.239$ & $2.18 \pm 0.258$ & $2.08 \pm 0.217$ & $1.91 \pm 0.256$ \\
\hline
\end{tabular}

* significantly different from control at the $95 \%$ confidence level

** significantly different from control at the $99 \%$ confidence level 


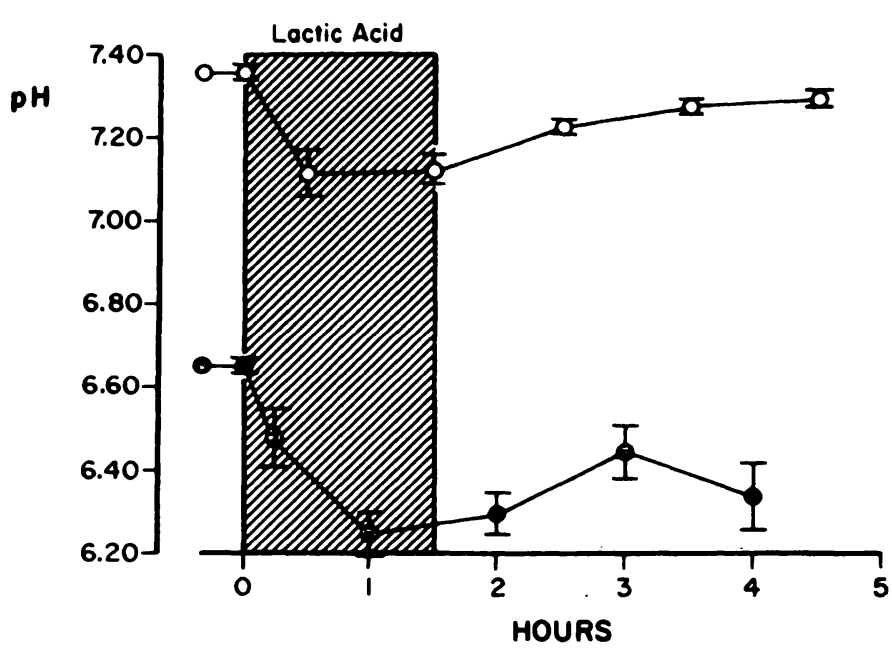

Fig. 1. Effect of lactic acid infusion on blood $(O)$ and urine (ब) $\mathrm{pH}$ in six experiments on 5 fetuses (Mean \pm S. E.).

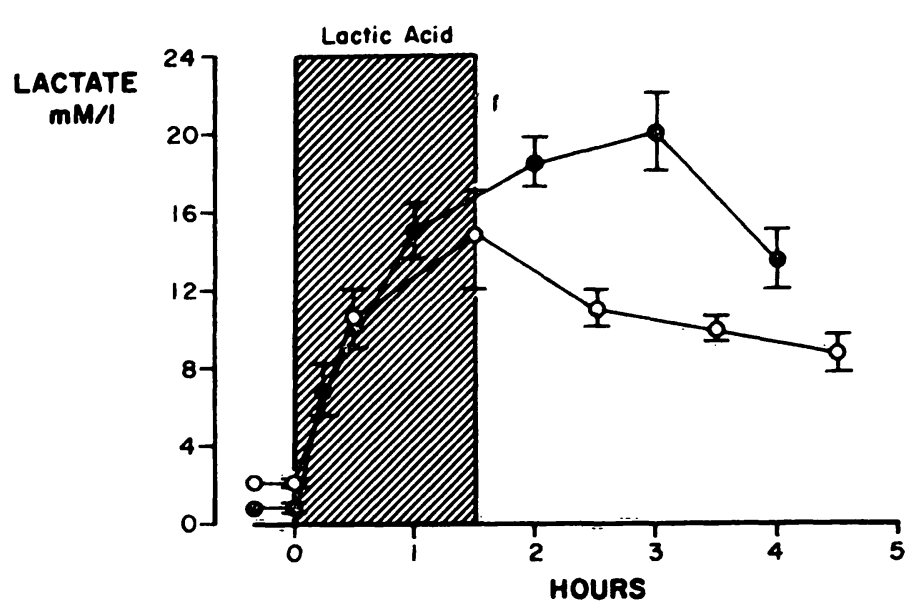

Fig. 2. Effect of lactic acid infusion on blood (O) and urine ( $\boldsymbol{S})$ lactate concentration in six experiments on 5 fetuses (Mean \pm S. E.).

Tab. III. Urine composition (mean \pm S. E.) in 6 experiments prior, during and following lactic acid infusion.

\begin{tabular}{|c|c|c|c|c|c|c|}
\hline $\begin{array}{l}\text { Interval in } \\
\text { minutes }\end{array}$ & 0 & $0-30$ & $30-90$ & $90-150$ & $150-210$ & $210-270$ \\
\hline $\mathrm{pH}$ & $6.650 \pm 0.211$ & $6.480 \pm 0.163$ & $6.252 * * \pm 0.075$ & $6.305 * * \pm 0.049$ & $6.452 \pm 0.083$ & $6.340 * \pm 0.081$ \\
\hline lactate $\mathrm{mM} / \mathrm{L}$ & $0.9 \pm 0.59$ & $6.8 * * \pm 2.48$ & $15.1 * * \pm 2.88$ & $18.4^{* *} \pm 2.48$ & $19.9 * * \pm 4.88$ & $13.5 * * \pm 3.03$ \\
\hline $\begin{array}{l}\text { osmolality } \\
\text { mOsm/kg }\end{array}$ & $170.4 \pm 9.10$ & $160.2 \pm 28.55$ & $180.2 \pm 37.00$ & $191.2 \pm 50.83$ & $219.4 \pm 51.79$ & $260.4 * \pm 35.00$ \\
\hline $\begin{array}{l}\text { sodium } \\
\mathrm{mEq} / \mathrm{L}\end{array}$ & $36.4 \pm 9.75$ & $41.5 \pm 4.50$ & $62.8 * \pm 13.70$ & $59.8 * \pm 9.60$ & $67.3 * * \pm 14.75$ & $48.7 \pm 12.78$ \\
\hline $\begin{array}{c}\text { potassium } \\
\mathrm{mEq} / \mathrm{L}\end{array}$ & $11.38 \pm 3.15$ & $7.78 \pm 2.68$ & $1.98 * * \pm 0.58$ & $1.62 * * \pm 0.40$ & $2.61 * * \pm 0.40$ & $3.33 * * \pm 0.98$ \\
\hline $\begin{array}{l}\text { ammonia } \\
\mathrm{mEq} / \mathrm{L}\end{array}$ & $2.10 \pm 1.01$ & $2.49 \pm 1.03$ & $1.35 \pm 0.35$ & $1.93 \pm 0.44$ & $3.12 \pm 0.89$ & $4.18 \pm 1.25$ \\
\hline $\begin{array}{l}\text { chloride } \\
\mathrm{mEq} / \mathrm{L}\end{array}$ & $16.6 \pm 3.35$ & $18.0 \pm 1.67$ & $24.8 \pm 9.27$ & $28.9 \pm 10.37$ & $24.6 \pm 6.53$ & $20.5 \pm 3.35$ \\
\hline $\begin{array}{l}\text { inorganic } \\
\text { phosphate } \\
\mathrm{mM} / \mathrm{L}\end{array}$ & $1.82 \pm 0.843$ & $2.40 \pm 0.937$ & $1.64 \pm 0.590$ & $1.55 \pm 0.651$ & $1.09 \pm 0.389$ & $0.80 \pm 0.267$ \\
\hline $\begin{array}{c}\text { bicarbonate } \\
\mathrm{mEq} / \mathrm{L}\end{array}$ & $6.17 \pm 0.82$ & $4.93 \pm 0.78$ & $3.55 * * \pm 0.38$ & $2.83 * * \pm 1.03$ & $3.20 * * \pm 0.71$ & $2.70 * * \pm 0.93$ \\
\hline $\begin{array}{l}\text { titratable } \\
\text { acid } \\
\mathrm{mEq} / \mathrm{L}\end{array}$ & $1.48 \pm 2.05$ & $4.93 \pm 3.77$ & $4.58 \pm 2.35$ & $5.73 \pm 3.77$ & $7.30 * \pm 3.68$ & $7.20 \pm 3.80$ \\
\hline
\end{tabular}

* significantly different from control at the $95 \%$ confidence level

$* *$ significantly different from control at the $99 \%$ confidence level

rise in $\mathrm{P}_{\mathrm{CO} 2}$ from 39 to a maximum of $45 \mathrm{mmHg}$ at 30 minutes; $\mathrm{P}_{\mathrm{O}_{2}}$ rose from 16 to $19 \mathrm{mmHg}$ and the rise persisted throughout the study. During the following three hours of recovery $\mathrm{pH}$ gradually rose to $7.29, \mathrm{~B}$. D. and lactate fell to $7.4 \mathrm{mEq} / \mathrm{L}$ and $8.7 \mathrm{mM} / \mathrm{L}$ respectively, and $\mathrm{P}_{\mathrm{CO}_{2}}$ returned to control values. Lactic acid infusion caused very little change in plasma osmolality 
although there was a tendency for a rise towards the end of the study. There was a fall in plasma electrolytes presumably due to dilution; this persisted throughout the experiment with regard to concentration of chloride and inorganic phosphate, while concentration of sodium and potassium returned to control levels.

Urine $\mathrm{pH}$ fell from 6.65 to 6.25 during the infusion and was 6.34 three hours later. Urine lactate rose from a mean control value of 0.9 to $15.1 \mathrm{mM} / \mathrm{L}$ during the infusion and after three hours, the concentration was $13.5 \mathrm{mM} / \mathrm{L}$; the highest urine concentration of lactate occurred 1-2 hours following the end of infusion reaching a mean of $19.9 \mathrm{mM} / \mathrm{L}$ (Tab. III, Figs. 1 and 2).

The infusion of lactic acid caused a diuresis (Fig. 3), urine output increasing from control values of 0.12 to $0.28 \mathrm{ml} / \mathrm{kg} / \mathrm{min}$ at the end of the infusion, returning to control rates three hours later. There was a prompt increase in renal excretion of lactate from 0.05 prior to infusion, to a maximum of $4.6 \mu \mathrm{mole} / \mathrm{kg} / \mathrm{min}$ at the end of infusion (Fig. 4, Tab. IV). Net acid excretion (titratable acid +ammonia - bicarbonate) also rose from a control value of -0.5 to a maximum of $1.4 \mu \mathrm{Eq} / \mathrm{kg} / \mathrm{min}$; this maximal rate occurred two hours after the end of the infusion. Three hours following the infusion, the values for net acid excretion was $1.0 \mu \mathrm{Eq} / \mathrm{kg} / \mathrm{min}$ and for lactate excretion $1.3 \mu \mathrm{mole} / \mathrm{kg} / \mathrm{min}$.

Osmolar and solute free water clearances both rose, indicating that diuresis was accompanied by an increase in solute excretion, particularly of sodium and chloride, whose rate of excretion increased by almost four fold (Tab. IV, Figs. 3 and 4). The rate of excretion of bicarbonate fell slightly while concentration fell significantly from 6.2 to $2.7 \mathrm{mEq} / \mathrm{L}$ three hours after the completion of infusion. There was a small but significant rise in excretion of inorganic phosphate from 0.54 to $1.66 \mu \mathrm{mole} / \mathrm{kg} / \mathrm{min}$ at the end of infusion, although the concentration fell from control value of 1.82 to a minimum of $0.80 \mathrm{mM} / \mathrm{L}$ after three hours of recovery. The fall in potassium concentration from 11.4 to a minimum of $1.6 \mathrm{mEq} / \mathrm{L}$ one hour after the infusion, was of sufficient degree to result in a decrease in potassium excretion from a control of 1.0 to $0.3 \mu \mathrm{Eq} / \mathrm{kg} / \mathrm{min}$,

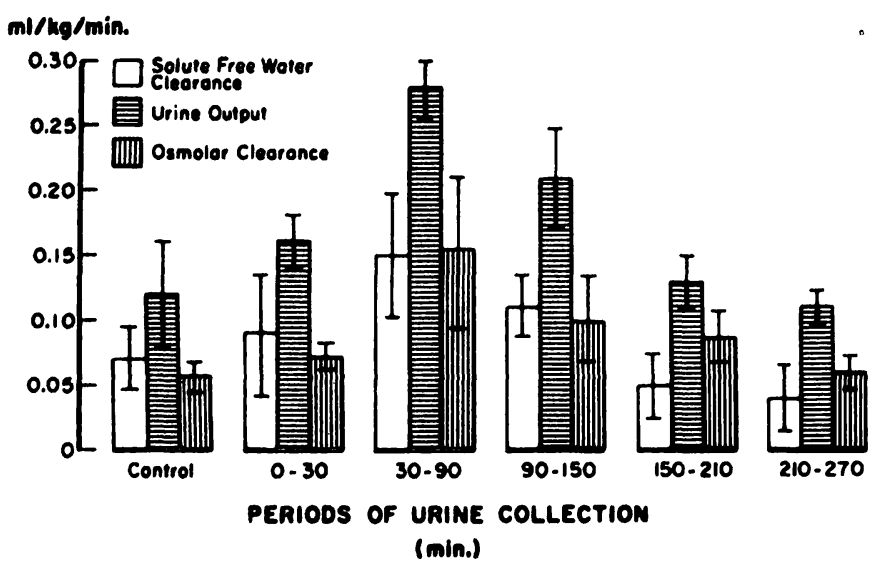

Fig. 3. Effect of lactic acid infusion on urine output, osmolar and solute free watcr clearances in six experiments on 5 fetuses (Mean \pm S. E.).

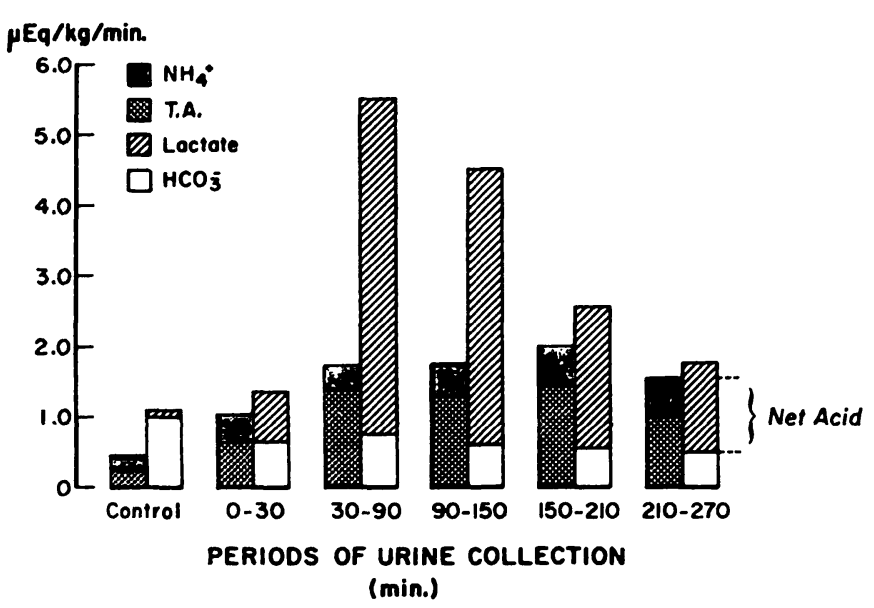

Fig. 4. Effect of lactic acid infusion on urine excretion of lactate and net acid (titratable acid + ammonia - bicarbonate) in six experiments on 5 fetuses.

which persisted throughout the experiment (Tabs. III and IV).

Twenty-four hours post infusion, acid-base and electrolyte composition of arterial blood and urine of fetuses studied were similar to the values obtained during the control period.

The mean $\mathrm{pH}$ of arterial blood of the unanesthetized pregnant ewe, prior to infusion, was $7.461 \pm 0.0089$, mean $\mathrm{P}_{\mathrm{CO} 2}$ was $29.9 \pm$ $1.07 \mathrm{mmHg}$, Base Deficit $2.11 \pm 0.633 \mathrm{mEq} / \mathrm{L}$ and $\mathrm{P}_{\mathrm{O} 2} 92.4 \pm 2.40 \mathrm{mmHg}$. These values were not significantly changed either immediately after infusing acid into their fetuses or three hours later. 
Tab. IV. Renal excretion (mean \pm S. E.) in 6 experiments prior, during and following lactic acid infusion.

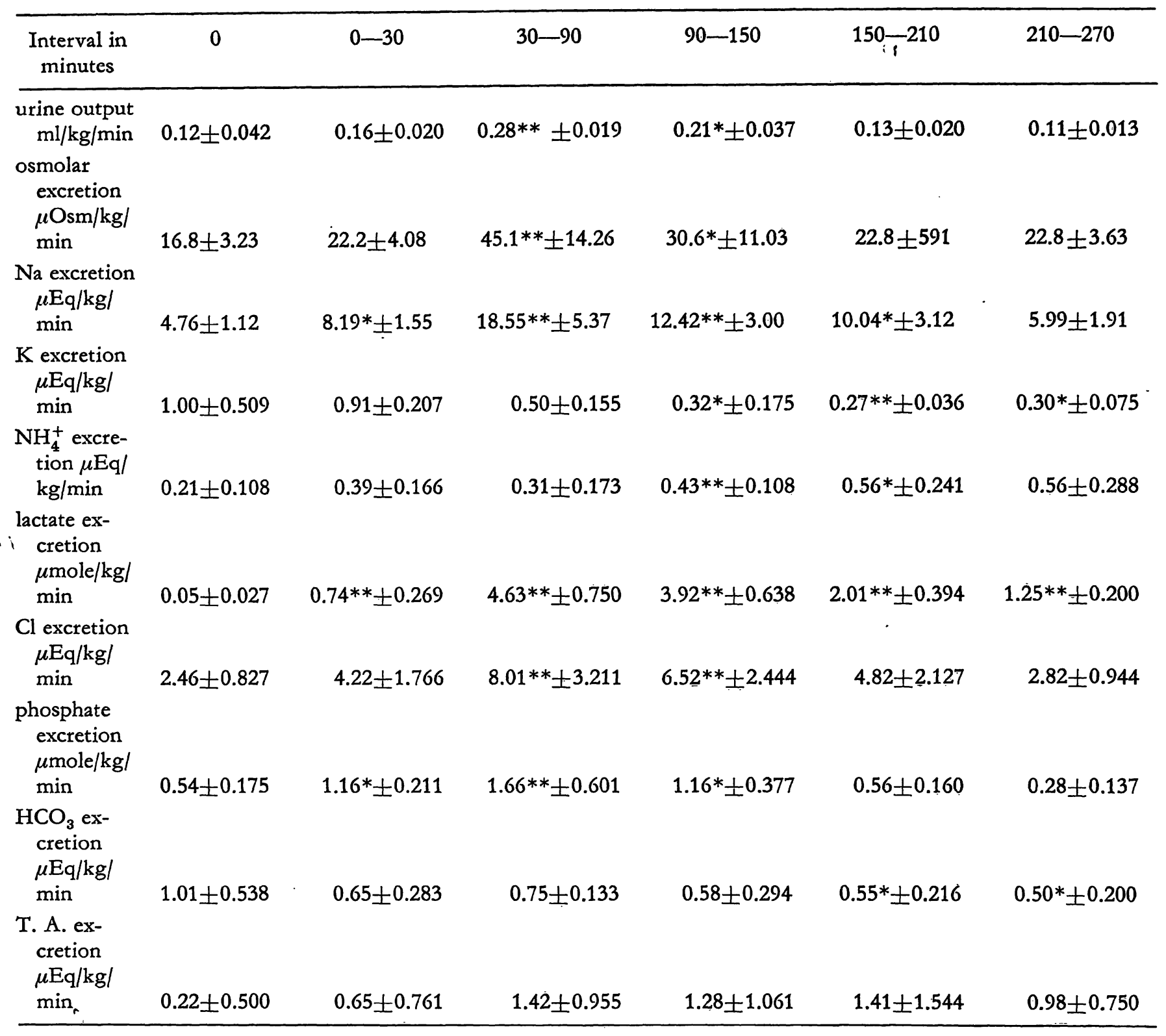

I* significantly different from control at the $95 \%$ confidence level

** significantly different from control at the $99 \%$ confidence level

\section{Discussion}

These experiments demonstrate that the kidney of the fetal lamb is capable of prompt increase in hydrogen ion excretion in response to acutely induced metabolic acidosis early in the third trimester. During the 90 minutes of infusion and the following three hours, a total of $800 \mu$ mole of lactate was excreted; however, hydrogen ion excretion over the same period amounted to less than half that amount. The rise in both phosphate and ammonia excretion in the fetal lamb was small compared to that achieved by human adults during acidosis [24] but was of a similar order of magnitude to response observed in both newborn lambs and human infants $[12,13,15,27]$. This is likely to be the principal reason for the limited ability of the fetus to eliminate the acid load through the kidney. In addition the sodium conservation mechanism was limited, excretion of sodium and chloride increasing more than threefold. Despite this limited renal contribution to acid-base 
homeostasis, both blood and urine composition had returned to control values by 24 hours. Thus the placenta and kidney of the well oxygenated fetus intact in utero are together capable, not only of eliminating the acid load, but of restoring base reserves lost during the diuresis and excretion of acid. The net effect, as has been shown in earlier experiments, is that recovery from an induced metabolic acidosis takes several hours to reach completion [11].

As noted above, the renal excretion of acid and lactate during the study period accounts for only a small portion of the acid infused. Although the animals received approximately $15 \mathrm{mEq} / \mathrm{kg}$ of acid, blood base deficit after three hours was around $7 \mathrm{mEq} / \mathrm{L}$. The increase in excretion of net acid (T.A. $+\mathrm{NH}_{4}^{+}-\mathrm{HCO}_{3}^{-}$) during the period of observation was nearly $0.4 \mathrm{mEq}$; excretion of lactate was approximately double. Therefore, the decrease in blood of lactate and base deficit during the recovery period is very likely due to equilibration in the various fetal compartments, placental transfer, as well as metabolism by the fetus.

Although sodium concentration in plasma fell during the infusion, the increased renal excretion of electrolytes which occurred during and following the infusion was not reflected by either plasma osmolality or sodium concentration, three hours after the end of the infusion. In addition no more than $20 \%$ of the water load infused was excreted by the kidney. This absence of change in plasma sodium or osmolality could be due to several factors including placental exchange of both water and electrolytes, equilibration with other fetal compartments, and possibly mobilization of fetal stores of sodium.

\subsection{Comparison with human infants and adults}

As noted above, the renal response to an acid load of the lamb fetus in utero was similar to that observed in premature and mature newborn infants and lambs. However, the increase in ammonia excretion in the lamb fetus was smaller than in human infants $[12,13,15]$. This difference could be due in part to the fact that ammonium chloride was used in human studies. The response was similar but somewhat greater in our experiments than in those reported in the exteriorized lamb fetus [27], even though the fetuses in the present experiments were quite immature. This could be due to differences in the two experimental preparations, the fetuses in utero having completely recovered from the effect of surgery and anesthesia. As in the exteriorized fetal lambs [27], the rise in urinary excretion of free hydrogen, phosphate and titratable acid was prompt while the maximum ammonia excretion occurred two to three hours following the end of acid infusion.

In the adult, prolonged metabolic acidosis also produces an initial diuresis and increased renal excretion of sodium and chloride [24]; the increase in chloride excretion is due to high plasma levels, sodium to achieve electrical equilibrium and the water obligatory. In the present fetal experiments, the anion introduced was lactate; the renal threshold and mechanism of tubular reabsorption for this ion are in all probability different from those of chloride; some of the increase in sodium excretion observed in the present experiments might be to balance the lactate. However, this does not explain the increase in excretion of solute free water and of chloride.

The diuresis and increased electrolyte excretion could be due to expansion of extracellular fluid volume [18]. Infusion of similar volumes of normal saline to fetal lambs of comparable gestational age also resulted in diuresis and increased electrolyte excretion; however, the diuresis occurred following the end of infusion and the increased electrolytes excreted during the experimental period was less than the amount infused [30]. Although animals and newborn infants are known to alter rates of excretion and urine flow by changing glomerular filtration rate (GFR) $[28,29]$, it is not known whether changes in GFR did occur in the present study. No consistent change in GFR was found during acidosis induced by a slow acid infusion to the exteriorized lamb fetus, although a diuresis was observed [27].

In the adult, the initial period of increase in sodium excretion during prolonged acidosis is followed by a period of increased potassium 
excretion; ammonium and phosphate are excreted later in order to conserve and restore the potassium and sodium stores. In the present experiments on lamb fetuses, no increase in potassium excretion was observed. This is probably due to the short duration of acidosis. However, the difference must also be due to immaturity of the fetal kidney since the net acid excreted was much lower than the excess lactate and chloride.

Acid infusion to the fetus caused a rise in arterial $\mathrm{P}_{\mathrm{CO} 2}$ due to the acid-bicarbonate reaction. As in previously published data from our laboratories [11], this increase was small and was followed by a

\section{Summary}

Response of the fetal kidney to metabolic acidosis was studied in five fetal lambs, 115-125 days gestation, in order to evaluate the renal contribution to elimination of hydrogen ion during intra-uterine development. Experiments were conducted on healthy unanesthetized fetuses, intact in utero, with catheters implanted at hysterotomy into a fetal femoral artery and vein and into the bladder via the urachus, four or more days prior to the study. A metabolic acidosis was induced by infusion of isotonic lactic acid, $15 \mathrm{~m} \mathrm{~mole} / \mathrm{kg}$, intravenously over a period of 90 minutes. Serial arterial samples were taken and urine collected in fractions, before, during and for three hours following the infusion, for measurements of $\mathrm{pH}$, bicarbonate, lactate and electrolytes as well as urine output.

During the infusion, urine $\mathrm{pH}$ fell from 6.65 to 6.25 and was 6.34 three hours later (Figs. 1 to 4, Tabs. III to IV). Lactic acid infusion caused a prompt increase in urine output from a mean rate of 0.12 to a maximum of $0.28 \mathrm{ml} /$ $\mathrm{kg} / \mathrm{min}$ at the end of the infusion, returning to control rates three hours later. Lactate excretion increased from 0.05 to a maximum of $4.6 \mu \mathrm{mole} / \mathrm{kg} / \mathrm{min}$ at the end of infusion; titratable acid increased from 0.22 to a maximum of $4 \mu \mathrm{Eq} / \mathrm{kg} / \mathrm{min}$; the rates of excretion of lactate and titratable acid were still higher than control at the end of three hours. Ammonia excretion increased from 0.21 to a maximum of $0.56 \mu \mathrm{Eq} / \mathrm{kg} / \mathrm{min}$ three hours after the end of infusion. The acid infusion caused a small but

Keywords: Acid-base state, fetus, kidney, lactic acid, lamb.

\section{Zusammenfassung}

Untersuchungen über die Reaktion der Nieren auf eine Säurebelastung beim gesunden, sich entwickelnden Lammfeten in utero

Um die Beteiligung der Niere bei der Ausscheidung von Wasserstoffionen während der intrauterinen Entwicklung return to control values soon after completing the infusion, indicating a rapid placental transfer of carbon dioxide.

i

It is not known whether the fetal kidney of other species will respond in a similar fashion to an exogenous acid load, because of differences in placental structure, or whether the response to endogenous production of acid, as a result of fetal asphyxia, would be the same. Nevertheless, it can be concluded that the kidney of the well oxygenated fetal lamb intact in utero is capable of prompt, although small, response to acid load and of contributing to fetal acid-base homeostasis.

significant fall in excretion of bicarbonate. During the 90 minutes of infusion and over the following three hours, about $800 \mu$ mole lactate was excreted while net acid excretion over the same period was no more than half that amount.

The diuresis was also accompanied by a net loss of sodium and chloride, the excretion of these ions increasing more than threefold following acid infusion; excretion of potassium decreased to one-third its rate prior to the infusion.

During the 90 minutes of infusion, blood $\mathrm{pH}$ fell from 7.36 to 7.13 , base deficit rose from 3.8 to $16.4 \mathrm{mEq} / \mathrm{L}$ and lactate rose from 2.2 to $14.8 \mathrm{mM} / \mathrm{L}$; there was also a small but significant rise in both blood $\mathbf{P C O}_{2}$ and $\mathbf{P O}_{2}$ (Figs. 1 to 2, Tabs. I to II). During the following three hours of recovery, $\mathrm{pH}$ rose gradually to 7.29 , base deficit and lactate fell to $7.4 \mathrm{mEq} / \mathrm{L}$ and $8.7 \mathrm{mM} / \mathrm{L}$ respectively. Since renal excretion of net acid and lactate was small, the decrease in blood base deficit and lactate levels during the recovery must therefore be mainly due to equilibration in various fetal compartments as well as placental transfer. These experiments indicate that, in the lamb fetus, intact in utero, the kidney although limited by immaturity of several mechanisms, is capable of responding to an acid load and thus can make a small contribution to fetal homeostasis. The increase in excretion of net acid is accompanied by loss of sodium and chloride in the urine. zu bestimmen, wurde die Reaktion der fetalen Niere auf eine metabolische Azidose bei 5 Lammfeten mit einer Tragzeit von 115-125 Tagen studiert. Die Experimente sind an gesunden, nicht anästhesierten, intakt in utero liegenden Feten durchgeführt worden, wobei 4 oder mehr Tage vor 
dem Experiment durch Hysterotomie Katheter in die fetale Femoralarteric und -vene und durch den Urachus in dic fetale Blase eingelegt worden waren. Durch i. v.-Infusion einer isotonischen Milchsäurelösung $15 \mathrm{mMol} / \mathrm{kg}$ über einen Zeitraum von $90 \mathrm{~min}$ wurde eine metabolische Azidose erzeugt. Vor, während und über 3 Stunden hinweg nach der Infusion wurden arterielle Blutproben entnommen und der Urin in Fraktionen gesammelt, um den pH-Wert, das Bikarbonat, dic Milchsäurekonzentration, die Elektrolyte und die Gesamturinmenge zu bestimmen.

Während der Infusion sank der pH-Wert von 6.65 auf 6.25 und betrug 3 Stunden später 6.34 (Figs. 1-4, Tab. III-IV). Die Milchsäureinfusion verursachte einen prompten Anstieg der Urinproduktion von einem mittleren Wert von 0.12 auf maximal $0.28 \mathrm{ml} / \mathrm{kg} / \mathrm{min}$ gegen Ende der Infusion; 3 Stunden später kehrten die Werte zur Norm zurück. Die Milchsäureausscheidung nahm von 0.05 auf maximal $4.6 \mathrm{mMol} / \mathrm{kg} / \mathrm{min}$ am Ende der Infusion zu. Die titrierbaren Säuren stiegen von 0.22 auf maximal $4 \mathrm{mÄ} / \mathrm{kg} / \mathrm{min}$ an. Die Ausscheidungsraten von Milchsäure und den titrierbaren Säuren lagen noch über den Kontrollwerten am Ende der 3. Stunde. Die Ammoniakausscheidung nahm von 0.21 auf maximal $0.56 \mathrm{mÄ} / \mathrm{kg} /$ min 3 Stunden nach Infusionsbeginn zu. Die Säureinfusion verursachte einen geringfügigen, aber signifikanten Abfall in der Bikarbonatausscheidung. Während der $90 \mathrm{~min}$ der Infusion und in den folgenden 3 Stunden wurden ungefähr $800 \mu \mathrm{Mol} / \mathrm{Milchsäure} \mathrm{ausge-}$ schieden, während die reine Säureausscheidung im selben Zeitraum nicht mehr als die Hälfte dieser Menge betrug. Die Harnflut war auch von einem Verlust von Natriumchlorid begleitet; die Ausscheidung dieser Ionen nahm nach Säureinfusion um mehr als einen Faktor $3 \mathrm{zu}$. Die Kaliumausscheidung ging auf ein Drittel ihres Wertes vor Infusion zurück.

Während der $90 \mathrm{~min}$ der Infusion fiel der Blut-pH-Wert von 7.36 auf 7.13, der Basendefizit nahm zu von 3.8 auf $16.4 \mathrm{mÄ} / 1$ und die Laktatkonzentration stieg von 2.2 auf $14.8 \mathrm{mMol} / 1$ an. Es wurde auch ein geringer aber signifikanter Anstieg des $\mathrm{Blut}-\mathrm{P}_{\mathrm{CO}_{2}}$ und $\mathrm{PO}_{2}$ beobachtet (Figs. 1 u. 2, Tabs. I u. II). Während der anschließenden, drcistündigen Erholungsphase stieg der pH-Wert graduell auf 7.29 ; der Basendefizit und die Laktatkonzentration fielen ab auf $7.4 \mathrm{mÄq} / \mathrm{l} \mathrm{bzw.} 8.7 \mathrm{~m} \mathrm{Mol} / 1$. $\mathrm{Da}$ die renale Ausscheidung von reiner Säure und Laktat gering war, muß gefolgert werden, daß das Absinken des Basendefizits und der Laktatkonzentration im Blut während der Erholungsphase vorwiegend auf die Äquilibrierung in den verschiedenen fetalen Kompartimenten als auch auf den plazentaren Transfer zurückzuführen ist.

Diese Experimente an intakten Lammfeten in utero weisen darauf hin, daß die Niere trotz ihrer unreifebedingten Funktionseinschränkung in der Lage ist, auf eine Säurebelastung zu antworten. Sie kann dergestalt einen kleinen Beitrag zur fetalen Homeostasis leisten. Die $\mathrm{Zu}$ nahme der reinen Säureausscheidung ist mit einem Verlust von Natrium und Chlor im Urin verbunden.

Schlüsselwörter: Fet, Lamm, Milchsäure, Niere, Säurebasenstatus.

\section{Résumé}

Reponse renale a l'administration d'ions acides au foetus de mouton in utero

Les auteurs ont étudié la réponse du rein foetal à l'acidose métabolique, chez cinq foetus de mouton, agés de 115 à 125 jours, afin d'évaluer la contribution du rein foetal à l'élimination de l'ion hydrogène pendant le développement intra-utérin.

Les expérimentations furent réalisées sur des foetus en bonne santé, non anesthésiés, après implantation de cathéters dans l'artère et la veine fémorales foetales, et dans la vessie, via l'ouraque, au cours d'une hystérotomie, effectuée quatre jours au plus avant l'étude.

On provoqua une acidose métabolique en perfusant par voie intraveineuse $15 \mathrm{~m}$ mole/ $\mathrm{kg}$ d'acide lactique isotonique en 90 minutes. On pratiqua en série des prélèvements de sang artériel et d'urine, avant, pendant et au cours d'une période de trois heures suivant l'arrêt de la perfusion, afin de mesurer le $\mathrm{pH}$, le bicarbonate, le lactate, les électrolytes et le débit urinaire.

Pendant la perfusion, le pH urinaire chuta de 6.65 à 6.25 et trois heures après l'arrêt de la perfusion, il était égal à 6.34 (Figs. 1-4, Tabs. III-IV). L'administration d'acide lactique provoqua une augmentation rapide du débit urinaire d'une valeur moyenne de 0.12 à un maximum de $0.28 \mathrm{ml} / \mathrm{kg} / \mathrm{min}$ à la fin de la perfusion. Le retour à une valeur normale se faisant au bout de trois heures. L'excrétion du lactate passa de 0.05 à une valeur maximale de $4.6 \mu \mathrm{mole} / \mathrm{kg} / \mathrm{min}$, à la fin de la perfusion. Les acides titrables augmentèrent de 0.22 jusqu'à $4 \mu \mathrm{Eq} / \mathrm{kg} /$ min. Les taux d'excrétion de lactate et d'acides titrables étaient encore plus élevés que les valeurs témoins trois heures après la fin de la perfụsion. L'excrétion d'ammonium passa de 0.21 à $0.56 \mu \mathrm{Eq} / \mathrm{kg} / \mathrm{min}$ trois heures après la fin de la perfusion. La perfusion d'acide provoqua une diminution faible mais néanmoins significative de l'excrétion de bicarbonates. Au cours des 90 minutes de la perfusion et pendant les trois heures suivant l'arrêt de celle-ci environ $800 \mu$ moles de lactate furent excrétéas, tandis que l'excrétion d'acide n'était que la moitié de cette valeur au cours de la même période.

$\mathrm{La}$ diurèse s'accompagna également de pertes importantes de sodium et de chlorure. L'excrétion de ces ions fut triplée après la perfusion d'acide; au contraire, l'axcrétion de potassium fut réduite au tiers de sa valcur normale. Pendant les 90 minutes de perfusion, le pH sanguin foetal chuta de 7.36 à 7.13 , le déficit de base passa de 3.8 à 
$16.4 \mathrm{mEq} / \mathrm{L}$ et le taux de lactate de 2.2 à $14.8 \mathrm{mM} / \mathrm{L}$; on observa aussi une augmentation faible mais significative de la $\mathrm{PCO}_{2}$ et de la $\mathrm{PO}_{2}$ (Figs. 1-2, Tabs. I-II). Pendant les trois heures suivant l'arrêt de la perfusion, le $\mathrm{pH}$ remonta progressivement à 7.29 , le déficit de base et le taux de lactate chuta à $7.4 \mathrm{mEq} / \mathrm{L}$ et $8.7 \mathrm{mM} / \mathrm{L}$ et respectivement.

Etant donné qué l'excrétion rénale d'acide et de lactate fut faible, la diminution du déficit de base et du taux de lactate pendant la période de récupération doit être due principalement à une équilibration dans les divers compartiments foetaux et au transfert placentaire.

Cette expérimentation montre que, chez le foetus de mouton, le rein, quoique limhité dans son action parl, immaturité de certains mécanismes, est capable de répondre aux injections d'ions acides, et donc, peut contribuer à l'homéostasie foetale. L'augmentation de l'excrétion d'acide s'accompagne d'une perte de sodium et de chlorure par les urines.

Mots-clés: acide lactique, équilibre acido-basique, foetus, mouton, rein.

\section{Acknowledgement}

This investigation was supported by United States Public Health Service, National Institute of Health Grant GM 09069.

\section{Bibliography}

[1] Alexander, D. P., D. A. Nixon, W. F. Widdas, F. X. Wohlzogen: Renal function in the sheep fetus. J. Physiol (Lond.) 140 (1958) 14

[2] Bagrnski, E. S., P. P. Foa, B. ZaK: Microdetermination of inorganic phosphate, phospholipids, and total phosphate in biologic materials. Clin. Chem. 13 (1967) 326

[3] Barker, S. B., W. H. Summerson: The colorimetric determination of lactic acid in biological material. J. Biol. Chem. 138 (1941) 535

[4] BeArD, R. W., E. D. Morris: Foetal and maternal acid-base balance during normal labour. J. Obstet. Gynaec. Brit. Cwlth. 72 (1965) 496

[5] Blechner, J. N., G. Meschia, D. H. Barron: A study of the acid-base balance of fetal sheep and goats. Quart. J. Exper. Physiol. Cog. Med. Sci. 45 (1960) 60

[6] Blechner, J. N., V. G. Stenger, D. V. Eitzman, H. Prystowsky: Effects of maternal metabolic acidosis on the human fetus and newborn. Amer. J. Óbstet. Gynec. 99 (1967) 46

[7] Bowe, E. T., R. W. Beard, M. Finster, P. J. Poppers, K. Adamsons, L. S. James: Reliability of fetal blood sampling. Amer. J. Obstet. Gynec. 107 (1970) 279

[8] Bowman, R. L., H. V. Trantham, P. A. Caulfield: An instrument and method for rapid, dependable determination of freezing-point depression. J. Lab. and Clin. Med. 43 (1954) 310

[9] Chez, R. A., F. G. Smith, D. Hutchinson: Renal function in the intrauterine primate fetus. I. Experimental technique; rate of formation and chemical composition of urine. Amer. J. Obstet. Gynec. 90 (1964) 128

[10] Cotlove, E., H. V. Trantham, R. L. Bowman: An instrument for, and method for automatic, rapid, accurate, and sensitive titration of chloride in biological samples. J. Lab. and Clin. Med. 51 (1958) 461
[11] Daniel, S. S., R. A. Baratz, E. T. Bowe, A. I. Hyman, H. O. Morishima, S. R. Sarcia, L. S. JAMES: Elimination of hydrogen ion by the lamb fetus and newborn. Pediat. Res. 6 (1972) 584

[12] EdelmanN, C. M., Jr., H. Borchis, J. RopriguezSoriano, H. Stark: The renal response of children to acute ammonium chloride acidosis. Pediat. Res. 1 (1967) 452

[13] Gordon, H. H., H. McNamara, H. R. Benjamin: The response of young infants to ingestion of ammonium chloride. Pediat. 2 (1948) 290

[14] Gresham, E. L., J. H. G. Rankin, E. L. Makowski, G. Meschia, F. C. Battaglia: An evaluation of fetal renal function in a chronic sheep preparation. J. Clin. Invest. 51 (1972) 149

[15] Hatemi, N., R. A. McCance: Renal aspects of acidbase control in the newly-born. III. Response to acidifying drugs. Acta Paediat. 50 (1961) 603

[16] Huckabee, W. E., J. Metcalfe, H. Prystowsky, D. H. Barron: Movements of lactate and pyruvate in pregnant uterus. Amer. J. Physiol. 20 (1962) 193

[17] Joergensen, K.: Titrimetric determination of the net excretion of acid/base in urine. Scand. J. Clin. Lab. Invest. 9 (1957) 1

[18] Levinsky, N. G., R. C. Lalone: The mechanism of sodium diuresis after saline infusion in the dog. J. Clin. Invest. 42 (1963) 1261

[19] McCance, R. A., E. M. Widdowson: Renal function before birth. Proc. Roy. Soc. B. 14 (1953) 488

[20] McCance, R. A., M. W. Stanier: The function of the metanephros of foetal rabbits and pigs. J. Physiol. (Lond) 15 (1960) 479

[21] McDougal, E. I.: The composition of foetal fluids of sheep at different stages of gestation. Biochem. J. 45 (1949) 397

[22] Meschia, G., F. C. Battaglia, P. D. Bruns: Theoretical and experimental study of transplacental diffusion. J. Appl. Physiol. 22 (1967) 1171 
[23] SANZ, M. C.: Ultramicro methods and standardization of equipment. Clin. Chem. 3 (1957) 406

[24] Sartorius, O. W., J. C. Roemmeit, R. F. Pirts: The renal regulation of acid-base balance in man. IV. The nature of the renal compensations in ammonium chloride acidosis. J. Clin. Invest. 28 (1949) 423

[25] Searcy, R. L., S. G. Gough, J. L. Korotzer, L. M. BERGQUIST: Evaluation of a new technique for estimation of urea nitrogen in serum. Amer. J. Med. Technol. 27 (1961) 255

[26] Siggard-ANDersen, O.: Blood acid-base alignment nomogram. Scand. J. Clin. Lab. Invest. 15 (1963) 211
[27] Smith, F. G., Jr., A. Schwartz: Response of the intact lamb fetus to acidosis. Amer. J. Obstet. Gynec. $106(1970) 52$

[28] SmrTh, H. W.: The kidney, structure and function in health and disease. Oxford University Press, New York 1951

[29] Strauss, J., K. Adamsons, L. S. James: Renal function of normal full-term infants in the first hours of extrauterine life. Amer. J. Obstet. Gynec. 91 (1965) 286

[30] Unpublished observations.

Dr. Salha S. Daniel

Division of Perinatal Medicine of the Departments of Anesthesiology,

Obstetrics and Gynecology and Pediatrics

College of Physicians and Surgeons

Columbia University

630 West 168th Street

New York, N. Y. 10032/USA 